\title{
Women and Healthcare Affordability After the ACA
}

\author{
Lois Kaye Lee, MD, MPH ${ }^{7}$ (D, Michael Carl Monuteaux, $S C D^{7}$, and \\ Alison Amidei Galbraith, $\mathrm{MD}, \mathrm{MPH}^{2,3}$
}

'Division of Emergency Medicine, Boston Children's Hospital, Boston, MA, USA; ${ }^{2}$ Department of Population Medicine, Harvard Medical School and Harvard Pilgrim Health Care Institute, Boston, MA, USA; ${ }^{3}$ Division of General Pediatrics, Boston Children's Hospital, Boston, MA, USA.

J Gen Intern Med 35(3):959-60

DOI: $10.1007 / \mathrm{s} 11606-019-05248-4$

(C) Society of General Internal Medicine 2019

\section{INTRODUCTION}

Women historically had specific challenges in affording and accessing healthcare prior to the Affordable Care Act's (ACA) expansion of insurance benefits in 2014. ${ }^{1}$ Compared with men, women were more likely to report cost-related access problems, have lower average incomes, and have greater use of healthcare services, including reproductive care. ${ }^{2}$ Costrelated barriers to healthcare were greater for uninsured and low-income women. ${ }^{1}$ After the ACA, gender rating, where women could be charged more than men for the same coverage in the individual insurance market, was prohibited. In addition, the ACA mandated maternity and preventive service coverage, including contraceptives, without cost sharing. ${ }^{1}$ Despite these improvements in insurance benefits, disparities in cost-related medication nonadherence still remain greater for women compared with men. ${ }^{3}$ With the unique healthcare affordability challenges among women, we hypothesized there would be differential effects of the ACA on healthcare affordability for women based on income level. The objective of this study is to analyze the effects of the $\mathrm{ACA}$ on healthcare and prescription medication affordability for women.

\section{METHODS}

We conducted difference-in-differences analyses to compare changes in outcomes related to healthcare and prescription medication affordability for women, by family income. We used data for women 19-64 years old from the National Health Interview Survey (NHIS), a nationally representative, annual, in-person survey conducted by the National Center for Health Statistics. Income was categorized into 3 groups: $\leq$ $138 \%$ of the federal poverty level (FPL), 139-399\% FPL, and $\geq 400 \%$ FPL. This study was deemed exempt by our institutional review board.

All analyses accounted for the NHIS design characteristics (Stata Version 14.0, StataCorp, College Station, TX). To estimate changes over time (pre-ACA 2010-2013 versus postACA 2014-2017) for each outcome, we calculated differences

Published online August 6, 2019 with $95 \%$ confidence intervals $(95 \% \mathrm{CI})$ within each income group. To compare changes over time between income groups, we calculated the difference-in-differences with $95 \%$ CI.

\section{RESULTS}

The study sample included an estimated 41,106,929 women: $25.7 \% \leq 138 \%$ FPL, $38.6 \% 139-399 \%$ FPL, and $35.8 \% \geq$ $400 \%$ FPL. Worry about paying for healthcare and inability to afford mental health counseling and prescriptions decreased in all income groups after the ACA (Table 1). Decreases in other affordability problems were reported only in the two lower income groups. For all outcomes, there were significantly larger relative decreases for women in the lowest compared with the highest income group.

\section{DISCUSSION}

After the ACA's 2014 insurance benefit expansions, women reported improvements in healthcare and prescription medication affordability. These are important gains for women given their unique challenges with obtaining and affording healthcare prior to the ACA. Our findings are consistent with other studies examining ACA coverage and affordability effects. These studies included men and women and have highlighted the impact of the Medicaid expansion in improving access and affordability for low-income populations. ${ }^{4}$ The ACA has been associated with reductions in delaying and not obtaining care due to cost and in having problems in paying medical bills for women, with greater improvements for lower income women. ${ }^{5}$ Our findings come with limitations: survey data have the potential for responder and recall bias; we were unable to test for state-level differences (i.e., Medicaid expansion status); and without a control group unexposed to the ACA, we can report association, but not causation, regarding ACA effects.

Improving healthcare affordability is critical to achieve optimal health. In our study, women reported improvements in healthcare and prescription medication affordability after the ACA. Improvements were demonstrated in all income levels, with greatest changes seen in low-income compared with high-income women. With continued threats to policies protecting women's health services, legislative and policy 
Table 1 Changes in Healthcare Affordability After (2014-2017) Compared with Before (2010-2013) the ACA for Women 19-64 Years Old

\begin{tabular}{|c|c|c|c|c|c|}
\hline \multirow[t]{2}{*}{$\overline{\text { Outcome }}$} & \multirow{2}{*}{$\begin{array}{l}\text { US estimate, } \\
2010-2013 \\
(\%)\end{array}$} & \multicolumn{3}{|c|}{$\begin{array}{l}\text { Percent difference after ACA } \\
\text { (percent delta (95\% confidence interval)) }\end{array}$} & \multirow{2}{*}{$\begin{array}{l}\text { Difference in percentage-point } \\
\text { change between FPL groups } \\
\leq 138 \% \text { FPL vs. } \geq 400 \% \text { FPL }\end{array}$} \\
\hline & & $\leq 138 \%$ FPL & $\begin{array}{l}\text { 139-399\% } \\
\text { FPL }\end{array}$ & $\geq 400 \%$ FPL & \\
\hline \multicolumn{6}{|l|}{ Healthcare affordability } \\
\hline $\begin{array}{l}\text { Worried about paying for } \\
\text { healthcare* }\end{array}$ & 38.9 & $\begin{array}{l}-7.33(-9.70 \\
-4.96)\end{array}$ & $\begin{array}{l}-5.46(-7.28 \\
-3.65)\end{array}$ & $\begin{array}{l}-2.06(-3.90 \\
-0.22)\end{array}$ & $-5.27(-8.29,-2.25)$ \\
\hline $\begin{array}{l}\text { Could not afford mental } \\
\text { health counseling }\end{array}$ & 4.2 & $\begin{array}{l}-1.42(-2.11 \\
-0.72)\end{array}$ & $\begin{array}{l}-0.65(-1.12 \\
-0.18)\end{array}$ & $\begin{array}{l}-0.36(-0.65 \\
-0.07)\end{array}$ & $-1.06(-1.80,-0.31)$ \\
\hline Could not afford specialist ${ }^{\dagger}$ & 7.6 & $\begin{array}{l}-2.68(-3.65 \\
-1.72)\end{array}$ & $\begin{array}{l}-1.40(-2.09 \\
-0.72)\end{array}$ & $\begin{array}{l}-0.25(-0.68 \\
0.18)\end{array}$ & $-2.44(-3.47,-1.40)$ \\
\hline Medication affordability & & & & & \\
\hline $\begin{array}{l}\text { Could not afford } \\
\text { prescriptions }\end{array}$ & 12.6 & $\begin{array}{l}-5.55(-6.70 \\
-4.40)\end{array}$ & $\begin{array}{l}-3.49(-4.28 \\
-2.71)\end{array}$ & $\begin{array}{l}-1.09(-1.55 \\
-0.64)\end{array}$ & $-4.46(-5.68,-3.23)$ \\
\hline Skipped doses to save* & 10.8 & $\begin{array}{l}-4.01(-6.12, \\
-1.90)\end{array}$ & $\begin{array}{l}-1.62(-3.10 \\
-0.14)\end{array}$ & $\begin{array}{l}-0.57(-1.49 \\
0.36)\end{array}$ & $-3.44(-5.75,-1.14)$ \\
\hline $\begin{array}{l}\text { Delayed filling prescription } \\
\text { to save* }\end{array}$ & 15.0 & $\begin{array}{l}-5.22(-7.61 \\
-2.84)\end{array}$ & $\begin{array}{l}-3.54(-5.23 \\
-1.85)\end{array}$ & $\begin{array}{l}-0.48(-1.50 \\
0.55)\end{array}$ & $-4.75(-7.34,-2.16)$ \\
\hline
\end{tabular}

Value in italics denotes statistical significance

* Only collected from 2013 to 2015

†Only collected from 2011 to 2015

efforts must continue to uphold coverage benefits for all women. ${ }^{6}$

Corresponding Author: Lois Kaye Lee, MD, MPH; Division of Emergency Medicine Boston Children's Hospital, Boston, MA, USA (e-mail: lois.lee@childrens.harvard.edu).

Funding This study was funded by the Network for Excellence in Health Innovation (NEHI).

\section{Compliance with Ethical Standards:}

Conflict of Interest: The authors declare that they do not have a conflict of interest.

\section{REFERENCES}

1. Salganicoff A, Ranji U, Beamesderfer A, Jurani N. Women and health care in the early years of the ACA: Key findings from the 2013 Kaiser
Women's Health Survey. Henry J Kaiser Family Foundation. 2014;(May):Publication \#8590. http://kff.org/womens-health-policy/report/women-and-health-care-in-the-early-years-of-the-aca-key-findingsfrom-the-2013-kaiser-womens-health-survey/.

2. Patchias EM, Waxman J. Women and health coverage: the affordability gap. Issue Brief (Commonwealth Fund). 2007:1-12.

3. Bhuyan SS, Shiyanbola O, Deka $\mathbf{P}$, et al. The Role of Gender in CostRelated Medication Nonadherence Among Patients with Diabetes. J Am Board Fam Med. 2018;31(5):743-751. doi:https://doi.org/10.3122/jabfm. 2018.05.180039

4. Antonisse L, Garfield R, Rudowitz R, Artiga S. The effects of Medicaid expansion under the ACA: Updated findings from a literature review. Kaiser Family Foundation. 2018;6(6):944-950.

5. Lee LK, Monuteaux MC, Everett W. Early Effects of the ACA on Women's Health Measures. J Gen Intern Med. 2018:3-5. doi:https://doi.org/10. 1007/s11606-018-4598-0

6. Murray SP. Save Women's Preventive Care Act. Congress.gov; 2017. https://www.congress.gov/bill/115th-congress/senate-bill/1045/text.

Publisher's Note Springer Nature remains neutral with regard to jurisdictional claims in published maps and institutional affiliations. 